\title{
Amelioration physical and chemical parameters of marl miocene doped with the pozzolan
}

\author{
Laila Mesrar ${ }^{1}$, Ahmed Banamar $^{1}$, and Raouf Jabrane ${ }^{2}$ \\ ${ }^{1}$ Normandie University, UNIHAVRE, CNRS, LOMC, 76600 Le Havre, France \\ ${ }^{2}$ Department of Earth Sciences, Laboratory of Georesources and Environment, Faculty of Science \\ and Technology of Fez, Morocco.
}

\begin{abstract}
Given the increasing exploitation of clay in Morocco for ceramic industry and for the purpose of the benefit reuse of this resource, a study is conducted in order to carry out the identification and characterization of Miocene marl after doping with pozzolan. The objective of this work is to improve the physicochemical characteristics of Miocene marl of Fez region, by doping it pozzolan at different contents: 5, 10,15 and 20\%. Physical and chemical characterization of this material was carried out before and after doping with pozzolan following various analytical technics, such as the Xray fluorescence and geotechnical investigation. The result of geochemical analysis showed a higher rate of aluminum oxide $\left(\mathrm{Al}_{2} \mathrm{O}_{3}\right)$, iron oxide $\left(\mathrm{Fe}_{2} \mathrm{O}_{3}\right)$ and titanium oxide $\left(\mathrm{TiO}_{2}\right)$. Further characterization of Atterberg limits have shown that the plasticity of doped materials increases. Similarly the mechanical behaviour of marls doped with pozzolan have significantly improved, providing a mechanical strength of obtained materials up to $670 \mathrm{~N}$ when firing at $1000^{\circ} \mathrm{C}$, compared to the raw marl.
\end{abstract}

\section{Introduction}

The use of clay resources by human, mainly in the manufacture of building materials, dates from antiquity. Clay is a cheap and abundant material. However its low mechanical strength and non -uniformity colour after cooking limits its added value. The addition of an organic reinforcement in a mineral matrix is often a solution to improve the implemented mechanical elements [1].

Economic issues related to the rising costs of these methods (long chemical processes), and their complications, therefore, leads to explore other simple and low cost manufacturing methods such as doping with external material. In this work, we evaluate the influence of doping with pozzolan the Miocene marl of the region of Fez (Morocco).

However, the estimation of these resources to develop new materials, most environmentally friendly has become a concern of both scientific and industrial aims. The activity of extraction rocks and minerals, whose product is mainly export-oriented, experienced the past three decades a significant decline. The recent global economic crisis

\footnotetext{
${ }^{*}$ Corresponding author: mesrarlaila@gmail.com
} 
has further complicated the situation because of the very significant decline in investment in the field of mineral exploration. It has resulted in an alarming decline in exports and even a reversal of the situation: Morocco became an importer of some very expensive minerals but nonetheless vital to its industry. It becomes capital and urgent to draw up an inventory (usage and needs) of many minerals available in Morocco to find alternative solutions (domestic substitute products that are competitive in the point of view of quality but also the cost). Therefore, selection and recovery of industrial rocks and minerals require the involvement of different disciplines in particular, recognition, geological mapping and mineralogical identification and characterization of technological specifications.

In particular, The Miocene marl substrates, which are abundant in the region of Fez, remain insufficiently appreciated. However, as regard to the new demands of the society in terms of sustainable development and energy saving, recovery of the clay and its use in building materials may be more environmentally sustained and become of scientific and industrial concern. It was also investigated from different points of view in literature [2, 3, 4, 5].

In this perspective, the doping of the marl with pozzolan rocks could increase the added value of the clay used in the technology and building industry. A major problems encountered by users of these materials is their fragility and high shrinkage induced by cooking and causing defects in the bricks [6], and can go until it bursts. In order to improve the material performance, the efficiency and the quality in the manufacture of this marl, we opted for doping by dry method this material by the pozzolan, at different percentages of 5, 10, 15 and $20 \%$. The results of this study allow us to conceive and suggest new improvements of the physicochemical and mechanical parameters for clay so as to rise the benefit use of this low cost material.

\section{Materials and methods}

\subsection{Material}

The marl Miocene of Fez presents two distinct facies by their colour and lithology: blue marls and yellow marls (Figure.1). These marls flush to the surface especially at the top of the hill of Koudiat Ben Jallik (Figure 2).

The basic raw material is a marl Miocene of the region of Fez (Figure 3) which is an outcrop in the eastern area of Fez (Figure 2) at the Ben Jallik quarry. This region is known for its expertise in the field of pottery and tiles. The importance of clay-based materials in the ceramic industry is due to their plastic properties [7] allowing final ceramic products to retain their shapes after firing. The process is complex because usually the shaped product depends on the mineralogical composition of the raw material and the nature and quantity of impurities in clay.

The grey or blue marls of Fez, attributed to the Vindobonian, form a powerful monotone series of great lithological homogeneity reaching in Fez almost at 1000m elevation (Figure 4).

The base of the series is constituted by transgressive facies (sand more or less consolidated passing to compact sandstones, locally crystalline sandy limestone, conglomerates) that can pass laterally or vertically to blue marls of the Tortonian, normally located above. Blue marls are very compact and show traces of stratification (Figure 5). They are often affected by at least three families of vertical, oblique and subhorizontal diaclases.

These marls constitute the regional substratum of the whole region and appear locally in the city center and in the valleys of the wadis Zitiune and Boufekranne. 
This marl is distinguished by its gray green or blue colour. The superficial layers of the latter are generally altered and become yellowish (Picture 2).

The rocks pozzolan selected for this study come from an open pit quarry, available in large quantities, the career of pozzolan is located at $40 \mathrm{Km}$ from the city of Fez.

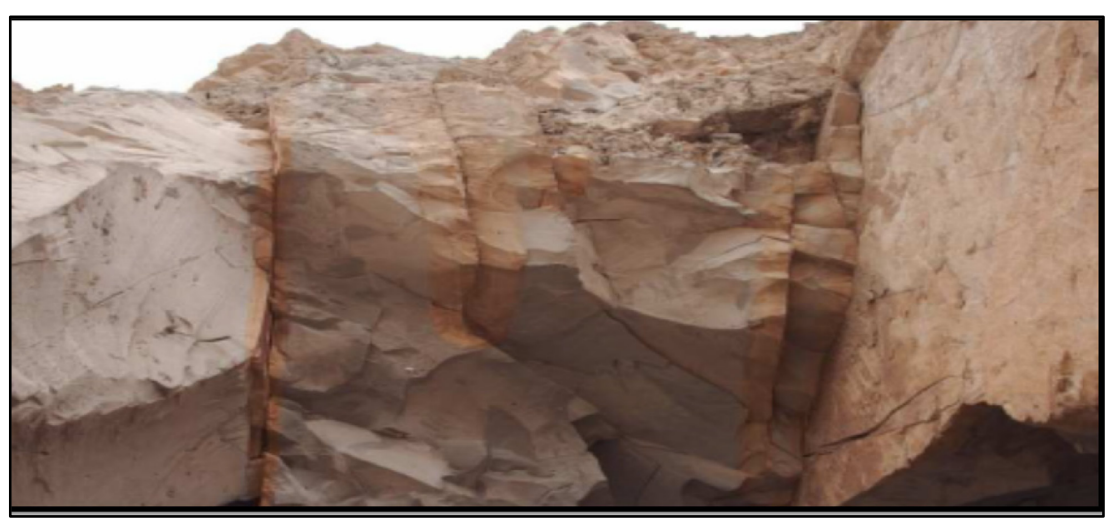

Fig. 1. A forehead of the career of Koudiat Ben Jallik.

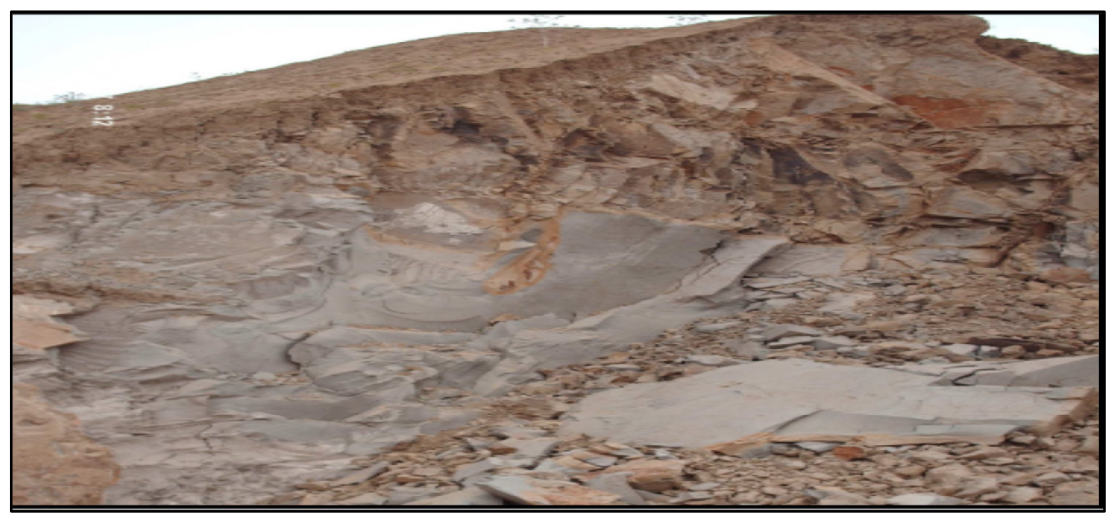

Fig. 2. Finely compacted marl of vertical diaclase. 


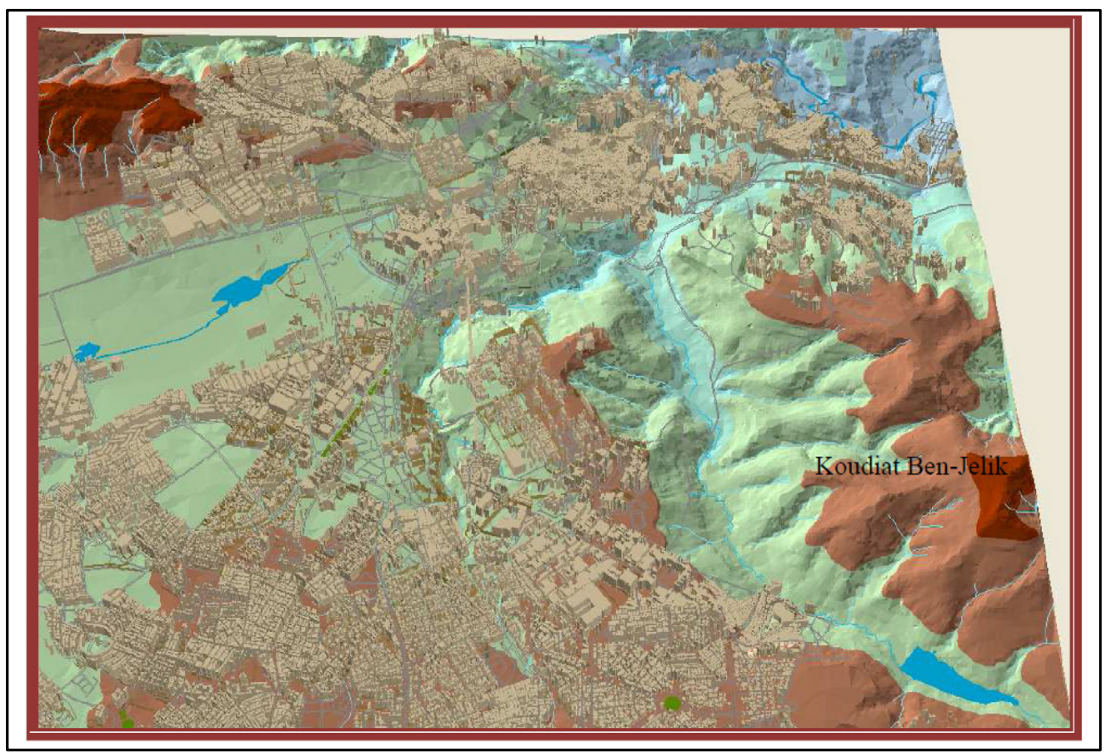

Fig. 3. MNT of the study area Koudiat Ben-Jalik.

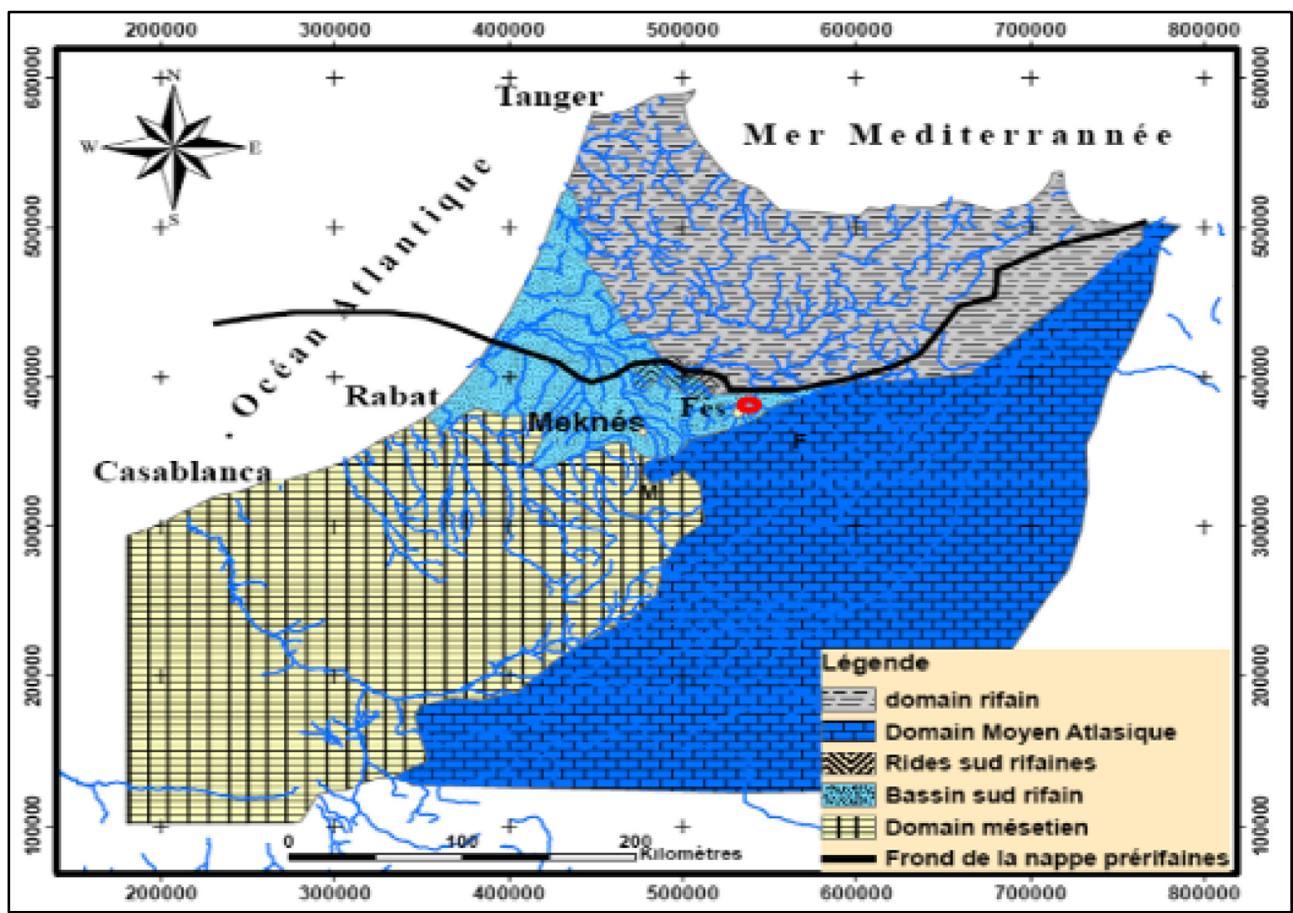

Fig. 4. The location and geological map of Fez area (Morocco) (Taltasse 1953, modify). 


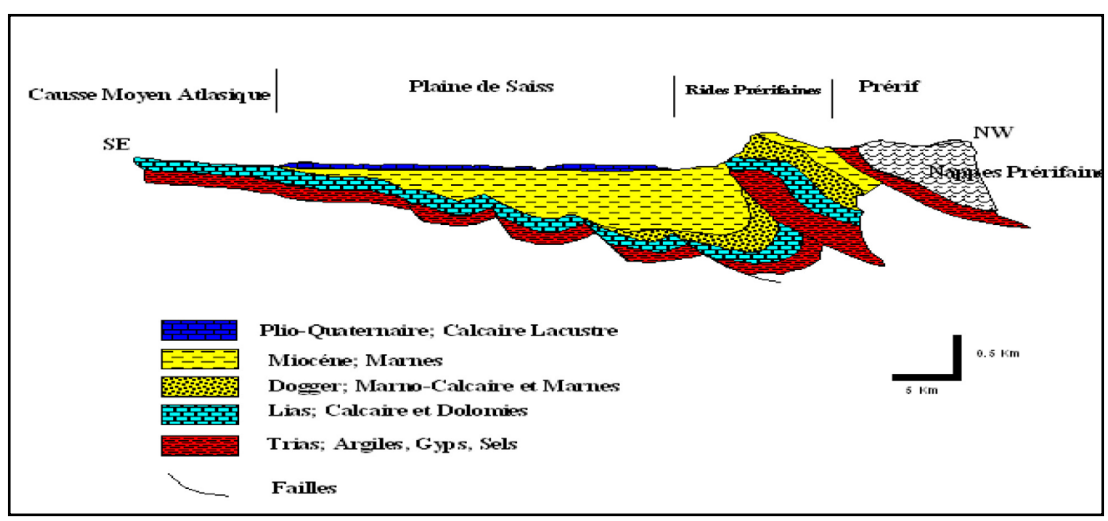

Fig. 5. Geological cross section of South Rif (DRH et ONI, 1971-1977).

\subsection{Preparation of composite marls / Pozzolan rocks}

Many methods have been developed for the synthesis of powders, which are widely used in laboratory research and industry [8].

The method used for mixing rocks pozzolan and marls involved three steps: mixing of precursors, reaction in solid and grinding. In the present study, we used the marl Miocene and doped by pozzolan at different percentages $(5,10,15$ and $20 \%)$.

\subsection{Methods}

In order to follow the homogeneity and the degree of pozzolan incorporation in the clay sheets several analysis/ techniques were used.

Chemical analysis: the quantitative chemical analysis of clays was performed by X-ray fluorescence spectrometry (WD-XRF) used spectrometer type Axios sequential brand Panalytical. This analysis was made after grinding the material and taking $10 \mathrm{~g}$ of each sample, and placed them in a hydraulic press, in order to make the pellets. The limits of detection of each element and error consideration for analysis are given in Table 1.

Mineralogical analysis: X-ray diffraction DRX study was done with the Philips diffractometer XPERT-PRO" PW 3064, with the Ka1, 2 radiation of copper. X-ray diffraction (XRD) data were obtained using oriented samples prepared on glass slides in the $2 \theta$ range of $2-40^{\circ}$ at a scanning speed of $2^{\circ} \min -1$.

The investigation of geotechnical properties of material was performed in the laboratory of geosciences and environment (university of Fez). The evaluation of plasticity was performed by the Casagrande method. The Atterberg limits are conventional physical constants indicating the clay transition from plastic to liquid state (WL) and from the plastic to solid state (WP). The plasticity index, which represents the difference between the liquid limit and plastic limit, defines the extent of the plastic field of clay.

Bricks production is carried out using a standard metal mold, provided for the operation. It has a length of and a width of $10 \mathrm{~mm}$. Bricks are previously dried in the open air until the stabilization of the withdrawal. They are fired in electric oven programmable to the temperatures of $900^{\circ} \mathrm{C}, 1000^{\circ} \mathrm{C}$ and $1100^{\circ} \mathrm{C}$, with a bake cycle of 30 minutes and a bearing of one hour and a half to the maximum firing temperature. The rate temperature of firing rise $10^{\circ} \mathrm{C} / \mathrm{min}$. The parameters resulting from the bricks firing are observed as the materials shrinkage along drying and firing, the ignition loss, and the mechanical resistance to compression. 


\section{Results and discussion}

\subsection{Chemical analysis}

The chemical composition of the samples were given in Table 1. The most abundant oxides in the samples were $\mathrm{SiO}_{2}, \mathrm{Al}_{2} \mathrm{O}_{3}$ and $\mathrm{Fe}_{2} \mathrm{O}_{3}$, whereas $\mathrm{MgO}, \mathrm{K}_{2} \mathrm{O}, \mathrm{Na}_{2} \mathrm{O}$ and $\mathrm{TiO}_{2}$ presented only in small quantities. Iron oxide $\left(\mathrm{Fe}_{2} \mathrm{O}_{3}\right)$ is the main colorant component, contents of Iron oxide being sensitive to firing and so lead to produce unexpected results in colour and texture of the fired clays [2]. The colour caused by iron oxide $\left(\mathrm{Fe}_{2} \mathrm{O}_{3}\right)$ depends on the changes in the ratio of $\mathrm{CaO}$. This might explain how high $\mathrm{CaO}$ contents may turn the colour to yellowish and pinkish shades [5]. Carbonates in clay samples are present in relatively higher content of $\mathrm{CaO}$ with was an indication of expressive calcite and dolomite. The low content of alkaline oxides $\left(\mathrm{K}_{2} \mathrm{O}, \mathrm{Na}_{2} \mathrm{O}\right)$ was a consequence of kaolinite clay that naturally have low flux materials content. The easiest way to determine the influence of a doping is to make measurements of tested material before and after doping.

Thus, analysis of the chemical composition by XRF marl doped with pozzolan reveals a significant enrichment in alumina $\left(\mathrm{Al}_{2} \mathrm{O}_{3}\right)$, iron oxide $\left(\mathrm{Fe}_{2} \mathrm{O}_{3}\right)$ and titanium oxide $\left(\mathrm{TiO}_{2}\right)$. Their concentration increases as the doping level is increasing.

However, doping causes a slight decrease in some major element remains like $\mathrm{CaO}$, which is varying quantitatively.

Table 1. Percentage of major elements of the crude marl (Z1) and doping with Pozzolan.

\begin{tabular}{|c|c|c|c|c|c|c|c|c|}
\hline Sample & $\mathrm{SiO}_{2}$ & $\mathrm{Al}_{2} \mathrm{O}_{3}$ & $\mathrm{CaO}$ & $\mathrm{Fe}_{2} \mathrm{O}_{3}$ & $\mathrm{MgO}$ & $\mathrm{K}_{2} \mathrm{O}$ & $\mathrm{Na}_{2} \mathrm{O}$ & $\mathrm{TiO}_{2}$ \\
\hline \multirow{2}{*}{$\mathrm{Z} 1$ Brut } & 42.3 & 13.1 & 9.18 & 7.63 & 3.2 & 1.02 & 1 & 0.33 \\
& 0.020 & 0.010 & 0.010 & 0.005 & 0.003 & 0.003 & 0.017 & 0.002 \\
\hline \multirow{2}{*}{ Pozzolan Brut } & 37.8 & 17 & 3.88 & 17.3 & 6.2 & 0.33 & 0.82 & 2.3 \\
& 0.020 & 0.010 & 0.010 & 0.005 & 0.003 & 0.003 & 0.017 & 0.002 \\
\hline \multirow{2}{*}{$\mathrm{Z} 1$ doped with 5\% } & 42.5 & 13.3 & 8.77 & 7.63 & 3.22 & 1.01 & 0.98 & 0.35 \\
& 0.020 & 0.010 & 0.010 & 0.005 & 0.003 & 0.003 & 0.017 & 0.002 \\
\hline \multirow{2}{*}{$\mathrm{Z} 1$ doped with 10\% } & 42.3 & 13.4 & 8.75 & 7.93 & 3.27 & 1.06 & 1.01 & 0.43 \\
& 0.020 & 0.010 & 0.010 & 0.005 & 0.003 & 0.003 & 0.017 & 0.002 \\
\hline \multirow{2}{*}{$\mathrm{Z} 1$ doped with 15\% } & 42.2 & 13.5 & 8.70 & 8.51 & 3.4 & 1.06 & 0.97 & 0.44 \\
& 0.020 & 0.010 & 0.010 & 0.005 & 0.003 & 0.003 & 0.017 & 0.002 \\
\hline \multirow{2}{*}{$\mathrm{Z} 1$ doped with 20\% } & 42.5 & 13.4 & 8.92 & 8.86 & 3.4 & 1.06 & 0.97 & 0.5 \\
& 0.020 & 0.010 & 0.010 & 0.005 & 0.003 & 0.003 & 0.017 & 0.002 \\
\hline
\end{tabular}

\subsection{Mineralogical analysis}

The mineralogical compositions of marl crude and doped showed significant differences, which reflects the change in the mineralogical structure of composites marl / pozzolan. The mineralogical compositions are reported in Figure 6, which refers to the relative abundance non-clayey minerals (quartz, calcite), and in small quantity the phyllite minerals (kaolinite, illite).

In all X-Ray diffraction of doped samples, we noted the appearance a hematite peak may be explained by the exchange between the pozzolan minerals and marl material. 


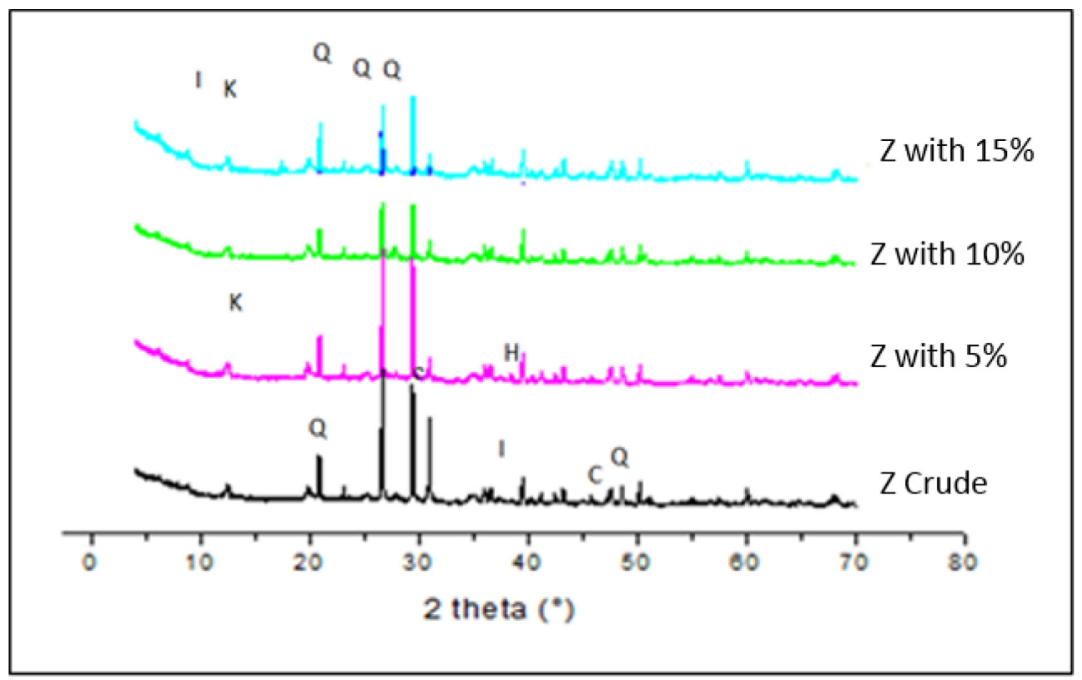

Fig. 6. Diffractograms RX of the raw sample z1 and doped with pozzolan at 5, 10 and 15. Q: quartz; C: calcite; I: illite; and K: kaolinite; H: Hematite.

\subsection{Geotechnical characterization (Atterberg limits)}

Based on the results of Table 2, we note that the raw material Z1 has an average plasticity that increases with the level of doping. However, the greater plasticity is observed in the doped marl with $20 \%$ pozzolan. Therefore we can deduce that the doping of this clay with pozzolan increases the plasticity of these materials. Previously this phenomenon was observed during handling.

Table 2. The results of plasticity and liquidity tests in the Samples.

\begin{tabular}{|c|c|c|}
\hline Sample & Liquid Limit (Wl) & Plastic Limit (Wp) \\
\hline Z1 Brut & 43.2 & 19.40 \\
\hline Z1 doped with 5\% & 43.2 & 27.40 \\
\hline Z1 doped with 10\% & 43.5 & 28.30 \\
\hline Z1 doped with 15\% & 43.3 & 29.40 \\
\hline Z1 doped with 20\% & 43.3 & 30 \\
\hline
\end{tabular}

As regards the Atterberg limits, we note that the calcareous crude clays (Z1) show an intermediate plasticity. The clay doped with 5,10 et $15 \%$ pozzolan rocks has a high plasticity and is more suitable for the use in bricks and pottery because it accounted for acceptable extrusion (Figure 7) . 


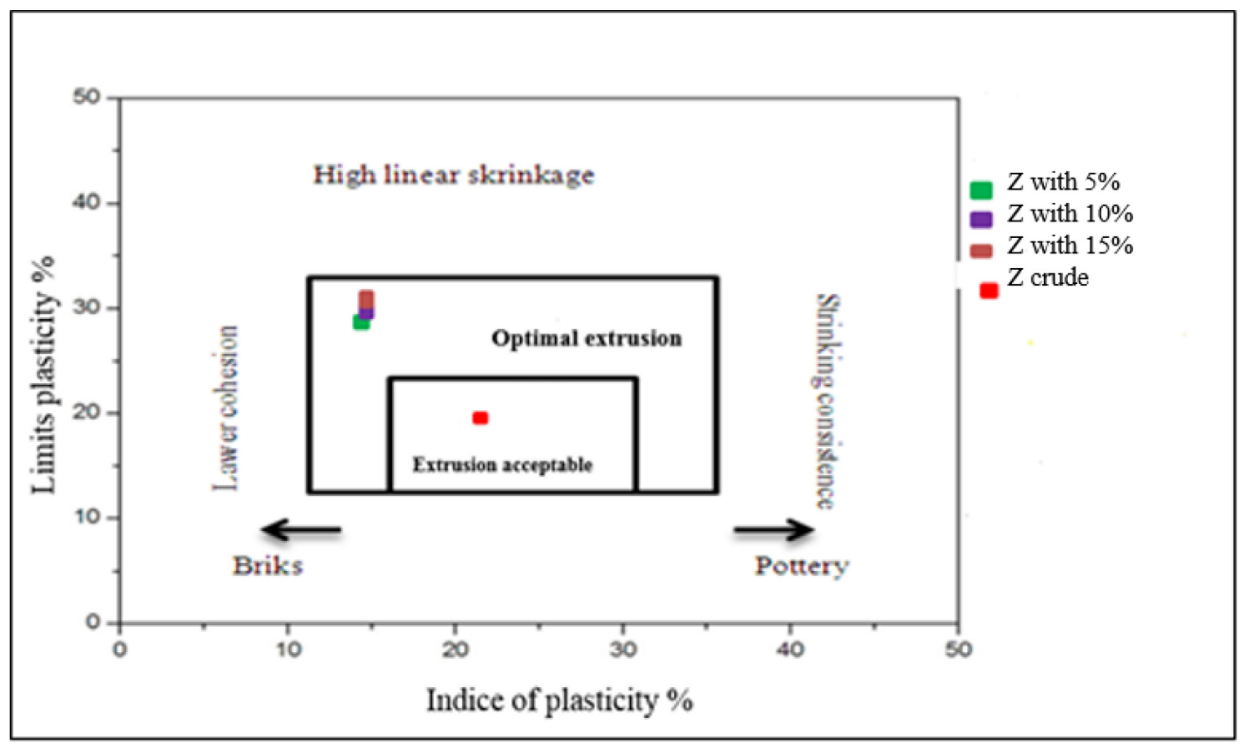

Fig. 7. Casagrande diagram with domains showing the optimum and acceptable domain for clay Shaping by extrusion (Highly, 1978 in [4].

\subsection{Effect of firing}

During the rise of firing temperature, the physicochemical transformations of the phase's marls affect the material (Figure 8). Each mineral in the mixture behaves as if it was alone. The decomposition products or new structural varieties, which take place under the influence of heat, react together to form new compounds [9].

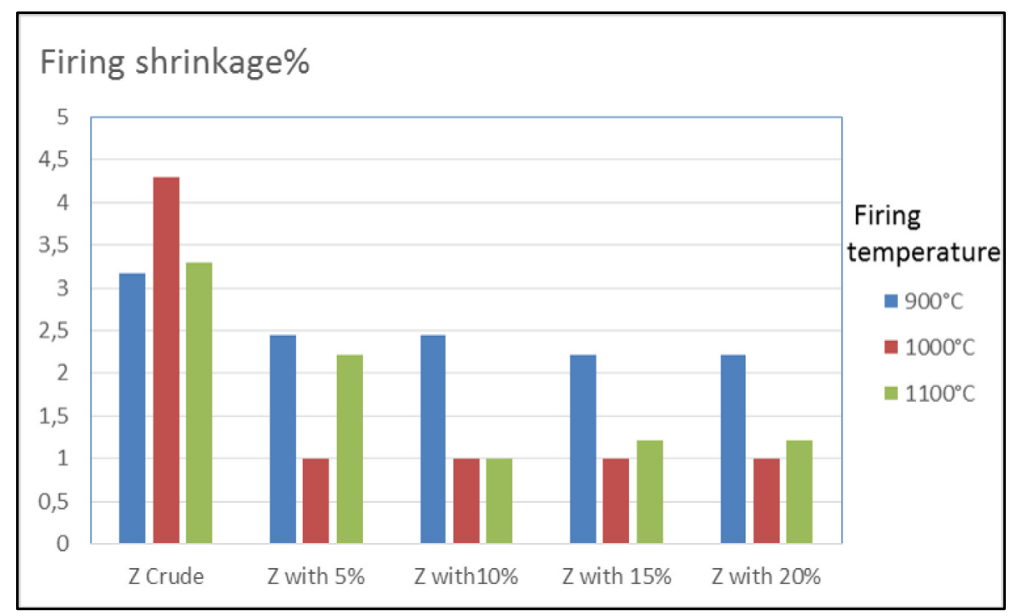

Fig. 8. Influence of firing temperature on the variation of linear shrinkage.

However, upon baking, the initial crystalline minerals disappeared and make space in varying proportions to an amorphous phase and new minerals [10].Shrinkage accompanies this solid reaction, and is associated with changes in porosity and particle size.

The proportions of the clay phase and / or associated minerals play an important role in these changes as well as the particle size [11]. Removing charged in the raw material is very important. This is due to the expansion case by new new-formed minerals [12]. 
In this study, all doped materials attended a shrinkage reduction until its cancellation. Therefore, being concluded the doping plays a role in limiting internal shrinkage. So we can conclude that the pozzolan plays a degreasing agent limiting withdrawal.

\subsection{Mechanical properties}

The bricks of marl doped at $10 \%$ of pozzolan have a relatively high resistance up to $525 \mathrm{~N}$ compared with bricks doped at 5\% (Figure 9). However, the increase in percentage of pozzolan is not indefinitely correlated positively with mechanical strength.

At $1000^{\circ} \mathrm{C}$, the bending strength increased from $900{ }^{\circ} \mathrm{C}$ in all the bricks and peaked its maximum $(670 \mathrm{~N})$ in the marl doped with $10 \%$ of the pozzolan. The explanation of the increase in resistance is linked to the modification of the crystalline structure of our marls [1], because at this temperature the vitrification begins and induces a stronger resistance.

At $1100^{\circ} \mathrm{C}$, overall, the flexural strength near a slight decrease estimated approximately $30 \mathrm{~N}$ this decrease can be attributed to a beginning of alvealing [7]. However, the marl doped with $10 \%$ displays a maximum resistant which that of $640 \mathrm{~N}$.

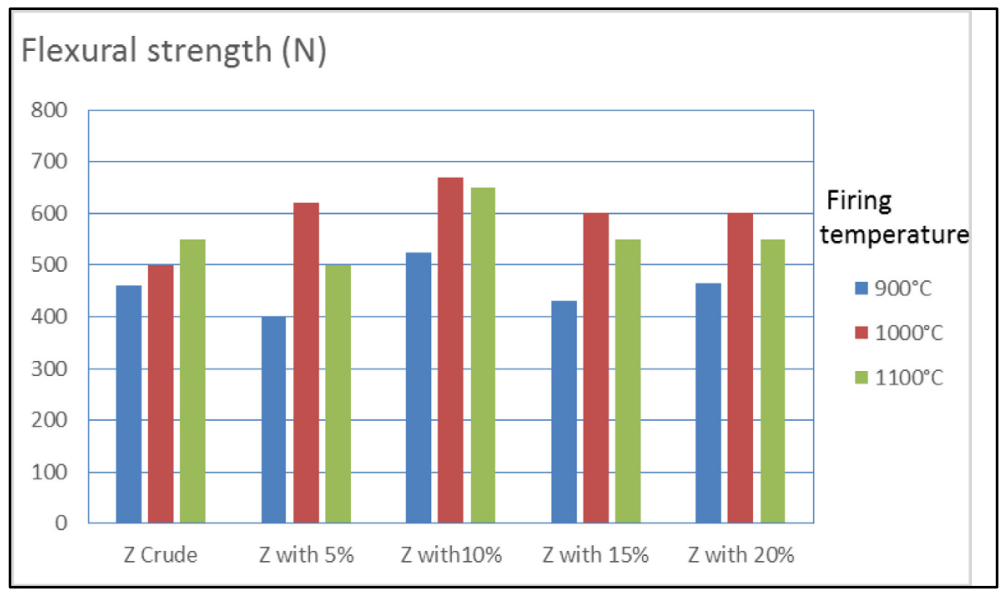

Fig. 9. The flexural strength of the bricks firing at different temperatures.

\section{Conclusion}

The results chemical analysis of marl doped with pozzolan reveals a significant enrichment in alumina $\left(\mathrm{Al}_{2} \mathrm{O}_{3}\right)$, iron oxide $\left(\mathrm{Fe}_{2} \mathrm{O}_{3}\right)$ and titanium oxide $\left(\mathrm{TiO}_{2}\right)$. The mineralogical analysis indicate the presence of Hematite peaks in all samples doping. Technological tests showed suitable industrial properties of these marls, their doping with pozzolan induced an increase in their plasticity. The pozzolan acts as a degreaser and decreases shrinkage.

The mechanical resistance of the doped bricks marl is dependent on quantity pozzolan doping and the temperature of firing. The marl doped with $10 \%$ has a relatively high resistance compared with bricks doped with 5, 15 and 20\%. Therefore, additional content of doping increases mechanical strength of bricks up to a certain amount less than $20 \%$.

This resistance is in fact related to the decrease of the porosity induced by the increase of the content of the doping. This causal relationship is in full agreement with the results obtained in the study of the porosity of the bricks. The bricks of marls fired at $1000^{\circ} \mathrm{C}$ and doped with $10 \%$ gives better mechanical strength of up to $670 \mathrm{~N}$. So, suggesting the use of this composite as eco-geo-materials in construction work, tiles and in pottery, is the main recommendation from the present study. 


\section{References}

1. L. Mesrar, and R.Jabrane. Characterization of Clays of the Sillon South Rif (Morocco), Clay Research, Vol. 33, No. 2, p 65-73 (2016).

2. L. Mesrar, O. El Aroussi, M. Lakrim, A. Lahrach, A. Chaouni, and R. Jabrane, Technological valorisation of the Miocene clay in the region of Fez (Morocco) : Characterisation and exploitation possibilities. PESD, VOL. 7, no.1, p 311-317(2013).

3. F. El Fgaier, Z. Lafhaj, C. Chapiseau. Use of clay bricks incorporating treated river sediments in a demonstrative building: case study. Constr. Build. Mater, no 48, p 160 165 (2013).

4. C. Fiori, B. Fabbri, G. Donati, I. Venturi. Mineralogical composition of the clay bodies, Appl. Clay Sci, 4, p $461-473$ (1989).

5. M. Bondi. Clay materials for ceramic tiles from the Sassuolo District Northern Apennines, Italy. Geology, composition and technological properties, Appl. Clay Sci, 15, p 337-366 (1999).

6. L. Mesrar, M. Akdim, M. Lakrim, I. Akhrif, and R. Jabrane. The physico-

7. Mechanical characteristics of the clays in and after doping with metal oxide $\mathrm{Al}_{2} \mathrm{O}_{3}$ in the region of fez (Morocco). PESD, vol. 9, no. 1, p 103-110 (2015).

8. L.Mesrar. Caractérisation chimique, mineralogique, technologique nanotechnologique des marnes du sillon sud riffain: Etude et valorisation. Thèse de Doctorat, soutenu à l'université de Fez (Maroc), p 200 (2013).

9. A.Baccour, A. Zghal, M. Medhioub, and T. Mhiri. Caractérisation Physicochimique et mécanique de matériaux céramiques obtenus à partir des argiles Tunisiennes, Verres, Céramiques / Composites, Vol.1. №2, p 25-33 (2011).

10. C.A Jouenne. Traité de céramiques et de matériaux minéraux. Ed. Septima, Paris, p 620 (1984).

11. M.J. Trimdade. Transformations of calcareous rich clays with firing: a comparative study between calcite and dolomite, Appl. Clay Sci .42, p 345 -355 (2009).

12. M. El ouahabi. Valorisation industrielle et artisanale des argiles du Maroc. Thèse de Doctorat, soutenu à l'université de liège, p 202 (2013).

13. S. Boussen, D. Sghaier, F. Chaabani, B. Jamoussi, A. Bennour. Characteristics and industrial application of the Lower Cretaceous clay deposits (Bouhedma Formation), Southeast Tunisia: Potential use for the manufacturing of ceramic tiles and bricks. Appl. Clay Sci. 123, p 210-221 (2016). 